\title{
Marzena Schneider
}

Uniwersytet Ekonomiczny we Wrocławiu

e-mail: marzena.schneider@adwokatura.pl

\section{WOLNOŚĆ JAKO STYMULANTA WYMIANY}

\section{FREEDOM AS A BOOSTER OF EXCHANGE PROCESS}

DOI: $10.15611 /$ pn.2018.529.26

JEL Classification: K20, K22, E02

\begin{abstract}
Streszczenie: W artykule zaprezentowano dyskurs o poszukiwaniu kompromisu pomiędzy sprawiedliwością a efektywnością w kontekście instytucjonalnego ograniczania przez imperium, którym jest państwo, wolności jednostki w należącej do niej sferze dominium. Wskazano na uwarunkowania konieczne do uzyskania przymiotu efektywności ograniczeń, które - mimo że wkraczają w obszar wolności gospodarowania - mogą przyczynić się do dobrobytu grupy i dodatnio wpływać na proces wymiany. Pokazano również zastosowanie, posiadających neoklasyczny rodowód, narzędzi mikroekonomicznych w procesie ekonomicznej analizy instytucji oraz autorsko użyto koncepcji wiązki praw własności do wyjaśnienia podlegającej ograniczeniu wiązki swobód.
\end{abstract}

Słowa kluczowe: wolność, własność, sprawiedliwość, instytucje.

Summary: The article presents a discourse about seeking a compromise between justice and efficiency. This has been explained in a context of institutionalised limitations to an individual freedom of property rights set by an imperium to an individual. Necessary determinants for the efficiency limitations have been pointed out, which - despite stepping into the area of economic freedom - are able to build a welfare society and have a positive influence on the process of an exchange. Further to this, the instruments of microeconomics (originating in neoclassicism) have been shown, in a context of an economical analysis of institutions. The author also draws and applies his original theory of property rights to explain limited crew of ease.

Keywords: freedom, property, justice, institutions.

\section{Wstęp}

Rozważaniom nad wolnością jednostki i całych grup społecznych w rozmaitym, uzależnionym od przedmiotu badań kontekście, poświęcono wiele miejsca w naukach społecznych, w tym w filozofii, socjologii, prawie i wreszcie w ekonomii. O wartości wolności dowodzi też niezliczona ilość aktów sztuki. Nie straciły one na 
aktualności z uwagi na ciągłą ingerencję w wolność w różnym stopniu i zakresie. Naukom ekonomicznym wolność nie pozostawała obojętna i choć milcząco uznawano jej istnienia jako warunek sine qua non zastosowania podstawowego modelu homo economicusa, to dopiero nowa ekonomia instytucjonalna, spoglądająca na rzeczywistość przez pryzmat tworzących ją instytucji, jest tym obszarem, na gruncie którego wyjątkowo płodnie wyjaśnić można relację pomiędzy wolnością a efektywnością działalności człowieka gospodarującego.

Filozofia pojęcie wolności przeciwstawiła zniewoleniu, podkreślając, że człowiek wolny pozostaje wówczas, kiedy doświadcza zupełnego braku ograniczeń. Jednocześnie w kwestii tej wypracowała implikowaną przez prawo i nauki polityczne koncepcję wolności pozytywnej i negatywnej, czyli wolności do czegoś (do działania, czynienia, zaniechania) i od czegoś (od ucisku, przymusu, wymagań, oczekiwań), której twórcą był niemiecki fillozof Georg Wilhelm Friedrich Hegel, łączący wolność z jednostką i jej odpowiedzialnością [Drużkowski, Sokół 1966, s. 275]. Wolności jednostki upatrywał on w jej zdolności do przeciwstawienia się przyrodzie jako bytowi niezależnemu od woli człowieka i do stworzenia nowej rzeczywistości będącej antytezą rzeczywistości zastanej [Zirk-Sadowski 2011, s. 61]. Jak słusznie skonstatował Leszek Nowak, wolność wcale nie jest „stanem naturalnym człowieka" (state of nature), albowiem z biologicznego punktu widzenia ma on wrodzoną podatność na uleganie słuszności silniejszego, nie zaś na samokontrolę własnej niezależności [Nowak 1991, s. 45], od czego bycie wolnym zależy.

Dla ekonomii jako nauki zajmującej się człowiekiem aspektowym, gospodarującym głównie poprzez zawieranie niezliczonej ilości kontraktów, wolność jest tym obszarem i przestrzenią, której kształt determinuje proces i skutki kontraktowania oraz wymiany. Jest jednocześnie oczywiste, że - wobec istnienia systemu społecznego - pełna wolność nie istnieje, podobnie jak nie istnieje wolny rynek, będący w istocie wyłącznie modelem służącym procesowi wyjaśniania. Wolność doznaje różnych ograniczeń instytucjonalnych, zarówno podmiotowych, jak i przedmiotowych $-\mathrm{z}$ reguły jako następstwo zastosowania jakiegoś kryterium sprawiedliwości i dążenia do realizacji celów o charakterze aksjologicznym. Istotne jest jednak to, że w konsekwencji ograniczeń wolności z reguły zyskowi jednych towarzyszyć będzie strata innych, a od ograniczeń tych, a zwłaszcza od rozwiązania kwestii negatywnych efektów zewnętrznych (external effects) owej ingerencji, uzależniona jest sprawność rynku z jednej strony oraz efektywność wyborów ludzkich i stanowiący sumę dobrobytów indywidualnych - dobrobyt ogółu z drugiej. Chodzi więc o to, aby instytucjonalna matryca ograniczeń wolności nie była dysfunkcjonalna z punktu widzenia tak wyznaczonej funkcji celu i dostarczała bodźców do angażowania się w wymianę.

W tym kontekście w artykule podjęty zostanie dyskurs naukowy o przenikaniu się dwóch wartości, a jednocześnie obszarów - wolności i efektywności, oraz skutkach takiej kombinacji. Rozważania prowadzone będą wokół odpowiedzi na pytanie, czy, kiedy i przy spełnieniu jakich warunków ograniczenie wolności może być 
stymulantą gospodarowania i nie będzie z perspektywy ekonomicznej dysfunkcjonalne. Dociekania te mają charakter teoriopoznawczy o podejściu prakseologicznym, stanowiąc wkład w poszukiwanie kompromisu pomiędzy sprawiedliwością a efektywnością z punktu widzenia ekonomicznej oceny instytucji. Mogą też prowokować do dyskusji o skutkach ograniczenia wolności dla efektywności.

Ekonomia głównego nurtu milcząco przyjęła, że człowiek aspektowy działa w warunkach nieskrępowanego, wolnego wyboru, a w procesie gospodarowania ograniczają go wyłącznie wybitnie ekonomiczne determinanty wyborów, jakimi są ceny i dochody. Równie milcząco przyjęła, że istnieją instytucje [North 1990, s. 3], które nie zyskały cechy zmiennej wyjaśniającej. Ten atrybut otrzymały dopiero $\mathrm{w}$ ramach podejścia instytucjonalnego. Tymczasem instytucje, podążając za myśleniem D.C. Northa, są ograniczeniami wolności jednostki wpływającymi na jej interakcje, w tym na jej wybory i ich konsekwencje. Determinowana nimi wolność w ograniczonym kształcie może oliwić wymianę, nie będąc dysfunkcjonalną, mimo że z pozoru ingerencja w nią w jakimkolwiek stopniu zawsze wymianę tę hamuje.

Głównym celem artykułu jest wykazanie, że wolność może być stymulantą w procesie wymiany i gospodarowania nawet wtedy, kiedy doznaje formalnych ograniczeń, zyskując taką cechę głównie poprzez kompensację szkód beneficjentom efektów zewnętrznych (externalities). Celem dodatkowym jest zaprezentowanie zastosowania narzędzi mikroekonomicznych do badania ekonomicznych skutków regulacji, w tym - na zasadzie analogii - użycie koncepcji wiązki praw własności.

\section{Wolność z perspektywy ekonomicznej}

Wolność była obiektem zainteresowania naukowego w ramach różnych dyscyplin naukowych. $Z$ ekonomicznego punktu widzenia wolność ma znaczenie dlatego, że wpływa na wybory człowieka, zwłaszcza wtedy, kiedy podejmuje on decyzje związane z gospodarowaniem i wymianą opartą na koncepcji dobrowolności stron. Z tej perspektywy ekonomia skupia swoją uwagę głównie na wolności gospodarczej, będącej pochodną lub częścią wolności i praw człowieka. Ukazując tę zależność, twierdzi, że jej ograniczenie jest zamachem na wolność w ogóle [Friedman, Friedman 2009, s. 79]. Dzieje się tak dlatego, że potrzeba zamiany jednej rzeczy na drugą są naturalnymi skłonnościami człowieka [Chodorowski 2002, s. 138], który do realizacji tej biologicznej, naturalnej skłonności przetrwania i instynktu bogacenia się musi działać w warunkach pełnej swobody. Przede wszystkim zaś urzeczywistnienie tych potrzeb zachodzi w sytuacji wolnego wyboru w odniesieniu do dysponowania przez racjonalną jednostkę własnym dochodem, jako elementu, bez którego wolność gospodarowania nie istnieje.

Konceptualizując i definiując wolność dla celów związanych z analizą ekonomiczną, konieczne jest odróżnienie wolności człowieka od wolności grup społecznych. Podział ten odzwierciedla dysonans eksplikacyjny wyznaczony przez indywidualizm metodologiczny i holizm poznawczy. Jest istotny dlatego, że pozwala 
na wyjaśnienie wolności jednostki, która jest najistotniejsza z perspektywy dokonywanych przez nią wyborów w sferze gospodarowania. Jednocześnie rozważania nad wolnością jednostki zachowują swój sens wyłącznie w kontekście systemu społecznego [Mises 2011, s. 242], budującego macierz instytucjonalną, w jakiej ona funkcjonuje. $Z$ wolnością społeczeństwa czy narodu mamy do czynienia wtedy, gdy zachodzi sytuacja samorządzenia, a zatem kiedy rządzą swoi, a nie obcy [Balcerowicz 2012, s. 16], co wcale nie oznacza, że w ramach tych rządów nie dochodzi do zniewolenia jednostki lub jakiejś grupy ludzi, znajdujących się pod jarzmem takich rządów.

O tym, kiedy jednostka pozostaje wolna, decyduje przede wszystkim jej stosunek, czy inaczej relacja, do adresata decyzji, którą jednostka ta w następstwie dokonanego uprzednio wyboru podejmuje, nie będąc w tej kwestii pod wpływem innych niż własne preferencji oraz standardów, ani żadnych ograniczeń zewnętrznych. Jednocześnie wolność jednostki, poza tą relacją, pozostaje determinowana poprzez stan jej rozwoju, samoświadomości, samokontroli i wreszcie dostępu do prawdziwej informacji. Tylko bowiem człowiek wyposażony w dostateczny zasób polegającej na prawdzie informacji, zabezpieczony skonkretyzowaną wiedzą, którego świadomość nie doznaje uszczuplenia, może kontrolować własne wybory i podejmować suwerenne decyzje, jako że wyłącznie nomotetyczna i prawdziwa wiedza jednostki pozwala jej na osiągnięcie tego, co w świetle preferencji jednostki jest słuszne [Nowak 1991, s. 244]. Jest więc wolny na tyle, na ile z wolności tej jest subiektywnie zdolny skorzystać w określonej, neutralnej strukturze i w alternatywnych sytuacjach.

Wolność lub jej brak realizuje się głównie w działaniu, poprzedzonym wyborem. $\mathrm{Z}$ tej perspektywy korzystanie przez człowieka $\mathrm{z}$ wolności sprowadza się $\mathrm{w}$ istocie do używania jej elementów składowych, jakimi są swobody. Na wzór ekonomicznego konceptu wiązki praw własności ${ }^{1}$ stanowią one wiązkę uprawnień, możliwych do zastosowania przy dokonywaniu wyboru i podejmowaniu decyzji oraz ich realizacji. Zbiór uprawnień własnościowych nazwany wiązką praw własności jest koncepcją nauk ekonomicznych określającą zakres, $\mathrm{w}$ jakim podmioty decyzyjne mogą posiadać, używać, rozbudowywać, ulepszać, przekształcać, konsumować, uszczuplać, niszczyć, sprzedawać, darować, pozostawiać w spadku, przenosić, obciążać hipoteką, wydzierżawiać oraz pożyczać czy wyłączać innych z użytkowania swojej własności, który wyznacza ramy prawne do alokacji zasobów i podziału bogactwa [Tyc 2016, s. 148].

Analogia wolności do własności wynika $\mathrm{z}$ faktu wprost proporcjonalnej zależności pomiędzy wolnością jednostki a wiązką jej uprawnień własnościowych, a w następnej kolejności pomiędzy efektywnością wymiany i wzrostem dobrobytu.

\footnotetext{
${ }^{1}$ Prawo prywatne kontynentalne, na wzór rzymskiego Corpus Iuris Civilis, odróżnia posiadanie (possessio) od własności (dominium) i każdemu z nich enumeratywnie przypisuje, w pewnym zakresie odmienny, zespół uprawnień, ekonomia natomiast nie dokonuje takiego rozróżnienia, posługując się wyłącznie koncepcją wiązki praw własności, nawet wtedy, kiedy z prawnego punktu widzenia nie zachodzi stosunek własności, tylko posiadania zależnego lub samoistnego [Samuel 2016, s. 184; Coote, Ulen 2011, s. 97].
} 
Z zasady, oparta na pełnej wolności wymiana jest efektywniejsza od tej, która zachodzi w warunkach ograniczeń, albowiem racjonalnie działający człowiek, niebędący niczym ograniczony, zawsze dokona efektywniejszego wyboru, kierując się kryterium maksymalizacji korzyści. Przetransferuje, czy inaczej dokona zamiany dobra o mniejszej wartości na dobro przedstawiające dla niego wartość wyższą.

Powyższe porównanie prowadzi do wyodrębnienia zespołu swobód będących pochodną wiązki praw własności, składających się na wolność w tym obszarze. Zawężenie to jest ewidentne i ukierunkowane na eksplikację wolności gospodarowania. $\mathrm{Z}$ tego względu pomija inne morfologiczne elementy wolności, jakimi są swobody o nieekonomicznym rodowodzie, nieistotne ekonomicznie lub o nieekonomicznym skutku. Dla przykładu można wskazać na swobodę wypowiedzi, swobodę myśli czy swobodę przekonań, które składają się na wolność, lecz ich wiązka nie składa się na wolność gospodarowania.

Relacja własności do wolności poprzez wiązkę praw i wiązkę swobód pozwala na wyspecyfikowanie fundamentalnych uprawnień własnościowych, którym odpowiadają skonkretyzowane swobody, przy wykorzystaniu jakich możliwa jest realizacja wiązki praw własności.

Zobrazowana w tabeli 1 analogia umożliwiła także usytuowanie swobody kontraktowania jako tej, która służy urzeczywistnieniu i wykorzystaniu każdego jednego uprawnienia składającego się na wiązkę praw własności. Przez to jest ona podstawowym narzędziem służącym do, będącego funkcją celu, efektywnego wykorzystania tych praw, zyskując status reguły konstytutywnej. Oznacza to, że ingerencja w wolność poprzez zahamowanie całkowite lub częściowe korzystania ze swobody kontraktowania determinuje zakres użycia uprawnień własnościowych począwszy od zakresu pełnego, aż do zupełnego wyłączenia. Następstwem tego jest wzrost kosztów transakcyjnych ochrony praw własności i będących ich wypadkową cen towarów i praw, co w konsekwencji kształtuje tendencje i relacje rynkowe.

Tabela 1. Analogia wiązki praw własności do wiązki swobód

\begin{tabular}{|c|l|l|}
\hline Lp. & \multicolumn{1}{|c|}{$\begin{array}{c}\text { WŁASNOŚĆ }- \text { WIĄZKA PRAW } \\
\text { WŁASNOŚCI }\end{array}$} & \multicolumn{1}{|c|}{ WOLNOŚĆ - WIĄZKA SWOBÓD } \\
\hline 1 & prawo do wyłącznego korzystania & $\begin{array}{l}\text { swoboda kontraktowania } \\
\text { swoboda używania } \\
\text { swoboda zarządzania }\end{array}$ \\
\hline 2 & prawo do wyłącznego pobierania pożytków & $\begin{array}{l}\text { swoboda kontraktowania } \\
\text { swoboda gospodarowania }\end{array}$ \\
\hline 3 & prawo do przenoszenia własności & $\begin{array}{l}\text { swoboda kontraktowania } \\
\text { swoboda wymiany }\end{array}$ \\
\hline
\end{tabular}

Źródło: opracowanie własne.

Sytuacja realizowania pełnej wolności jednocześnie przez wszystkie jednostki żyjące w określonej grupie społecznej jest nie do zaakceptowania z uwagi na poja- 
wiające się zaburzenia społeczne i negatywne tego skutki, będące efektem swoistej tyranii silniejszych. Dotyczy to w szczególności wolności gospodarowania, gdzie drapieżność indywidualnych jednostek jest wyjątkowo duża. Z tego też względu tak rozumiana wolność doznaje ograniczeń ze strony aparatu organizacji, która uposażyła go w kompetencje kształtowania formalnych reguł gry społecznej w gospodarce [North 1990, s. 234]. Najczęściej jest nim rząd, to jest podmiot wykonawczy struktury społecznej, jaką jest państwo. Kompetencje w tym zakresie realizuje on poprzez tworzenie instytucji formalnych, czyli norm prawnych. Stanowi to egzemplifikację umowy społecznej (social contract), będącej porozumieniem ukierunkowanym na zwiększenie bogactwa i osiągnięcie minimum bezpieczeństwa, gdzie w zamian za przekazanie uprawnień do stanowienia tych reguł, do wkroczenia w sferę wolności jednostki i jej swobód jako narzędzi wykonawczych, oczekuje się nie tylko zinstytucjonalizowanej ochrony praw cywilnych, ale też wspomnianego wzrostu bogactwa [Justyńska, Justyński 2013, s. 71]. Z jednej strony więc zadaniem państwa jest ochrona praw własności jako tych, które wykorzystywane w pełni za pomocą wiązki swobód finalnie prowadzą do wzrostu dobrobytu będącego sumą korzyści krańcowych wszystkich jednostek. $Z$ drugiej natomiast celem tym pozostaje zapobieganie wyżej wspomnianej tyranii silniejszych i ochrona słabszych przed następstwami ich naturalnej przewagi. Ten drugi cel wynika z respektowania rodowodu państwa jako organizacji realizującej zespół wartości o charakterze aksjologicznym, przy przyjęciu niepoddającego się obiektywizacji kryterium sprawiedliwości, gdzie normy prawa jako instytucje formalne tworzone są na fundamencie wartości [Skorupka 2013, s. 191]. Z tego względu państwo i zintegrowany system społeczny tej organizacji stanowią pochodne ideologii, która decyduje o kształcie porządku społecznego [Mises 2011, s. 162-163].

Ta dwoistość wzajemnie wykluczających się celów, czyli dążenia do urzeczywistnienia przez rządy nieobiektywnej sprawiedliwości, z jednoczesnym zadaniem osiągnięcia obiektywnej efektywności systemu społeczno-gospodarczego, rodzi potrzebę kompromisu i odnalezienia takiej postaci ingerencji państwa w indywidualną wolność gospodarowania, która poprzez instytucjonalne odbieranie lub ograniczenie swobód na rzecz realizowania przez nie aksjologicznych wartości co najmniej zrekompensuje straty poszkodowanym i w ostatecznym rozrachunku doprowadzi do sytuacji sumarycznego wzrostu dobrobytu całej zbiorowości. Straty te bowiem pozostają efektem zewnętrznym ingerencji w wolność gospodarowania, stanowią bezpośrednie następstwo naruszania swobód korzystania z wiązki praw własności, są policzalne, poddają się obiektywizacji i składają się na tzw. koszty zewnętrzne (external cost) [Coote, Ulen 2011, s. 50]. Trzeba przy tym zwrócić uwagę, że pod pojęciem straty, czy szerzej - szkody, poniesionej w następstwie takiej ingerencji mieszczą się zarówno straty rzeczywiste, jak i utracone korzyści, które z prawdopodobieństwem graniczącym z pewnością mogłyby być uzyskane przez tych, których wyżej wskazane, autorytarne oddziaływanie doprowadziło do sytuacji gorszej. Tak rozumiana powinność władzy publicznej zaprzecza anglosaskiej formule king 
can't wrong i jest wyrazem nie tylko dążenia do kształtowania instytucji formalnych i zbudowanego z nich systemu prawa w sposób efektywny, ale także poszanowania autonomicznej pozycji jednostki wobec państwa [Safjan 2003]. Respektowanie przez państwowe imperium tego, co jest składową sfery prywatnej, a więc dominium jednostki, możliwe jest nie tylko przy braku jakiegokolwiek władczego wkraczania w ten obszar autonomii człowieka, ale także wówczas, kiedy władztwo państwa skierowane jest w jej stronę.

\section{Ekonomiczne i instytucjonalne uwarunkowania ograniczenia wolności kontraktowania}

Odebranie pewnym grupom jednostek lub poszczególnym ludziom ich wolności gospodarczej w zakresie odnoszącym się do praw własności ${ }^{2}$ ma miejsce wtedy, gdy dochodzi do zawłaszczenia części lub wszystkich swobód korzystania z tych praw, w tym swobody zawierania umów, których przedmiotem jest wejście w posiadanie rzeczy, wyłączne używanie jej i pobieranie pożytków, a w tym zmiana przeznaczenia rzeczy i jej samej oraz pozbycie się rzeczy w jakikolwiek sposób.

Instytucjonalne odbieranie jednostce przez państwo swobody do działania i zaniechania $\mathrm{w}$ tym zakresie dokonywane jest po to, aby realizować zasady sprawiedliwości społecznej oraz chronić słabszych. Ze względu na to, że ludzie, realizując swoją wolność, nie są równi, nie mają tych samych możliwości podmiotowych oraz nie cieszą się jednakowym dostępem do informacji ${ }^{3}$, potrzebnej do skutecznego realizowania własnych interesów i prowadzenia wyrównanej walki w procesie wymiany i gospodarowania [Becker 2013, s. 161], to ochrona słabszych i wyrównywanie tych dysproporcji na rzecz jednych odbywa się kosztem innych. Nie jest bowiem w takich uwarunkowaniach możliwa zmiana, w której po poprawie sytuacji jednych nie dochodzi do pogorszenia się sytuacji kogokolwiek z podmiotów takiego oddziaływania, co dla przyjęcia efektywności rozwiązań instytucjonalnych wymagane jest przez kryterium Pareto.

Przykładów wkraczania państwa w tak rozumianą wolność jednostki, a więc w jej obszar użyteczności, jest wiele, w zależności od celu takiej ingerencji. W istocie sprowadza się ono do krzywdzenia przez władzę osób poszkodowanych w imię wsparcia słabszych. Takie sprawowanie przez państwo imperium w sferze dominium będzie efektywne tylko wtedy, kiedy stanowi wyraz ostatecznej kalkulacji dobrobytu całej grupy, mimo zaburzenia naturalnej konkurencji oraz wzrostu cen zasobów, których ono dotyczy. Dokonana w ten sposób zmiana, oprócz kalkulacji kosztów

\footnotetext{
${ }^{2}$ Ingerencja państwa w wolność działalności gospodarczej ma szerszy, wykraczający poza artykuł, wymiar i odnosi się również do ograniczenia podejmowania działalności gospodarczej i jej form.

${ }^{3}$ Asymetria informacji, według twórcy tego pojęcia G.A. Akerlofa, występuje wtedy, gdy sprzedający wiedzą więcej niż kupujący, a więc gdy wiedza stron potrzebna do zawarcia kontraktu nie jest tożsama [Akerlof 2005, s. 475-476].
} 
i korzyści, których suma musi być ostatecznie mniejsza od dodatnich efektów ingerencji władzy, dla stwierdzenia, że wkroczenie w cudzą sferę użyteczności i przysługujące mu uprawienie do korzystania jest efektywne, wymaga wyrównania strat wyrządzonych takim działaniem. Jednocześnie straty te, a więc zarówno ujemne skutki rzeczywiste, jak i utracone korzyści, powinny być zrekompensowane przez tych, którzy zyskali najwięcej. Takie rozumienie efektywności poprzez zastosowanie testu kompensacji jest następstwem myślenia o zmianach instytucjonalnych w ujęciu koncepcji efektywności Kaldora-Hicksa [Munzer 1990, s. 200]. Dobrym przykładem kompensacyjnego podejścia państwa do ingerencji w sferę użyteczności jednostki poprzez pozbawienie jej własności są instytucjonalne rozwiązania związane z wywłaszczeniem [Banaszak (red.) 2001, s. 177]. Państwo władczo pozbawia jednostkę prawa własności z uwagi na to, że wyłącznie przy użyciu przedmiotu tego prawa może zrealizować cel publiczny i dokonać redystrybucji dóbr, ale czyni to za odpowiednim odszkodowaniem. Odszkodowanie takie ma funkcję kompensacyjną, jest zindywidualizowane in concreto i uwzględnia wszystkie szczególne okoliczności odnoszące się zarówno do przedmiotu szkody, jak i do osoby poszkodowanej, a jego zapłata jest de facto kalkulacyjnym uporaniem się z efektami zewnętrznymi takiej ingerencji państwa i osiągnięciem progu efektywności.

Instytucjonalna ingerencja w wolność jednostki, odbieranie lub redukcja swobód jako narzędzi, które decydują o tym, czy możliwe jest korzystanie w ogóle z praw własności, jest ingerencją nie tylko w samo prawo własności i w reguły o konstytutywnym charakterze, ale także w będące wypadkową tych rozwiązań oraz stanowiące determinantę rozwoju, prawa rynku i konkurencji. W celu oliwienia systemu decyzja o wprowadzeniu tego rodzaju zmiany nie może być kompulsywna. Rozważania nad efektywnością wdrożenia modyfikacji instytucjonalnej winny mieć miejsce ex ante, a nie ex post, w szczególności w zakresie zdolności do wypłacenia kompensacji ${ }^{4}$. Pomocnym narzędziem dla tych rozważań jest analiza marginalna podstawowych wielkości ekonomicznych, jakimi są korzyści oraz koszty, pozwalająca na optymalizację podejmowanych decyzji w zakresie rozwiązania, które zamierza się wprowadzić.

Przenosząc powyższe rozważania na grunt konkretnego przypadku, wskazać można zespół regulacji, czyli instytucji wprowadzonych przez państwo w odniesieniu do żywienia dzieci i młodzieży, w ramach których ustanowiony został formalny zakaz sprzedaży w placówkach szkolnych pieczywa z ciasta głęboko mrożonego, zawierającego dużą ilość stabilizatorów, barwników, konserwantów i innych polepszaczy, wywołujących szereg chorób, m.in. astmę i problemy skórne [Rozporządzenie z 26 lipca 2016, par. 1 ust. 1 pkt 1]. Niewątpliwie ustanawiając zakaz sprzedaży produktów takiego pochodzenia, państwo zaingerowało w sferę wolności

\footnotetext{
${ }^{4}$ Warunek ten ustanowił Tibor Scitowski i składa się on na tzw. kryterium Scitowskiego, obejmujące zalecenie, aby korzystający ze zmian mieli możliwość rekompensaty strat poszkodowanym oraz aby poszkodowani nie mogli nakłonić beneficjentów do zaniechania dążeń do wypłaty odszkodowań [Scitovszky 1941, s. 77-88].
} 
producentów, sprzedawców i konsumentów, gdyż każdemu z nich odebrało swobodę kontraktowania w odniesieniu do ich własności, począwszy od wprowadzenia takich produktów do obrotu, poprzez zwieńczenie procesu wymiany na płaszczyźnie konsumpcji. Uzasadnieniem tego rozwiązania była troska o dobrostan słabszych jednostek społecznych, którymi są dzieci. Taka ingerencja w wolność gospodarczą, a więc siłowa, bo zabezpieczona przymusem państwa, zmiana instytucjonalna, poza realizacją racji sprawiedliwościowych o aksjologicznym rodowodzie może zyskać jednocześnie atrybut efektywnej, jeżeli suma kosztów poniesionych w jej następstwie, a polegających na zmniejszonych wpływach podatkowych pochodzących od dostawców i sprzedawców, opłat administracyjnoprawnych nałożonych na te podmioty gospodarcze oraz ponoszonych przez konsumenta dochodów z podatków obrotowych, będzie mniejsza od ekonomicznych korzyści, jakie ostatecznie przyniesie to rozwiązanie. Wysokość tych korzyści wynika z zysków, mających swoje odbicie w kosztach, które musiałoby ponieść państwo w walce ze zdrowotnymi skutkami chorób cywilizacyjnych osób dorosłych, wynikających ze spożycia towarów wytworzonych $\mathrm{z}$ tego rodzaju produktów. Do efektywności takiej zmiany konieczne jest także zrekompensowanie tracącym na niej tych strat, które pozostają w związ$\mathrm{ku} \mathrm{z}$ tą ingerencją, albo bezpośrednio w postaci odszkodowania, albo też pośrednio poprzez politykę podatkową czy instytucje włączające producentów i sprzedawców w tak kreowany rynek szczególnych konsumentów, aby nie mieli się oni gorzej. Pozostawienie pełnej wolności w tym wypadku, a więc brak instytucjonalnej ingerencji w swobodę kontraktowania i zgoda na sprzedaż produktów żywnościowych takiego pochodzenia, nie byłoby efektywne, gdyż nie prowadziłoby do wzrostu dobrobytu zbiorowości. Koszty transakcyjne zdobycia przez każdego z rodziców informacji o szkodliwości spożywania przez ich pociechy tego typu żywności i koszty jej internalizacji przewyższałyby ryzyko związane z takim żywieniem, co ostatecznie doprowadziłoby do przerzucania części kosztów leczenia schorzeń stanowiących tego skutek na podatników, którzy ze swojej wolności w tym zakresie korzystali świadomie i kalkulacyjnie. $Z$ tego powodu taka ingerencja państwa w swobodę kontraktowania i wyłącznego decydowania o prawach własności nie jest dysfunkcjonalna i posiada przymiot efektywności.

\section{Zakończenie}

Instytucje są ograniczeniami wpływającymi na wolność jednostki, a czasem całych grup w obrębie danego społeczeństwa. Zadaniem państwa jest sprawiedliwy podział dóbr i ochrona słabszych oraz działanie w sposób efektywny, aby finalnie budować dobrobyt grupy. Realizacja tego celu możliwa jest poprzez tworzenie takiej matrycy instytucjonalnej, która z jednej strony doprowadzi do urzeczywistnienia zasad sprawiedliwości społecznej, z drugiej zaś nie będzie ekonomicznie dysfunkcjonalna. Trudność w pogodzeniu tych dwóch porządków uwidacznia się zwłaszcza na gruncie przysługującej jednostce swobody do wykorzystania należącej do 
niej wiązki praw własności, składającej się na wolność gospodarowania i wolność w ogóle. Szczególnie zatem wtedy, kiedy państwo przy zastosowaniu swojego imperium dopuszcza się ograniczenia tak rozumianej wolności, nadanie tego rodzaju zmianom cechy efektywności stanowi kluczowe narzędzie dyskursu w teorii wyboru publicznego i w ramach poszukiwania optymalnych rozwiązań oraz decyzji interwencyjnych rządu w sferę prywatną jednostki. Mikroekonomia stworzyła katalog narzędzi do weryfikacji efektywności działań człowieka. Jednocześnie wyjaśniła zagadnienie efektywności oraz nadała mu niesporną treść. W ostatnim czasie nauki ekonomiczne zajęły się też problematyką uprawnień własnościowych i na potrzeby dyskursu o efektywności wyborów ekonomicznych stworzyły katalog nazwany wiązką praw własności. Wiązce tej odpowiada zespół swobód, które składają się na wolność gospodarowania i determinują możliwość oraz zakres użycia praw własności, a w dalszej części także osiągnięcie optimum właścicielskiego. Efektywność gospodarowania, do którego dochodzi poprzez kontraktowanie, uzależniona jest nie tylko od wybitnie ekonomicznych, cenowo - dochodowych ograniczeń, ale także od instytucji, które decydują o tym, czy dane działanie zyska tę cechę. Zespół rozwiązań prawnych, składających się na otoczenie instytucjonalne, a konstruowanych w sposób uwzględniający potrzebę stymulacji wymiany, w tym rekompensaty negatywnych efektów ingerencji władzy w jej przestrzeń, jest zbiorem instytucji formalnych właściwych prawu spełniającemu postulat efektywności.

\section{Literatura}

Akerlof G.A., 2005, Explorations in Pragmatic Economics, Oxford University Press, Oxford.

Balcerowicz L., 2012, Odkrywając wolność. Przeciw zniewoleniu umysłów, Zysk i S-ka, Poznań.

Banaszak B. (red.), 2001, Przeglad Prawa i Administracji, t. XL, Wydawnictwo Uniwersytetu Wrocławskiego, Wrocław.

Becker G.S., 2013, Nieoczywistości. Ekonomiczna teoria wszystkiego, Oficyna a Wolters Kluwer business, Warszawa.

Chodorowski J., 2002, Adam Smith 1723-1970, Wydawnictwo Uniwersytetu Wrocławskiego, Wrocław.

Coote R., Ulen T., 2011, Ekonomiczna analiza prawa, C.H. Beck, Warszawa.

Drużkowski M., Sokół K., 1966, Antynomie wolności. Z dziejów filozofii wolności, Książka i Wiedza, Warszawa.

Friedman M., Friedman R., 2009, Wolny Wybór, Aspekt, Sosnowiec.

Justyńska I., Justyński J., 2013, Historia myśli socjologiczno-ekonomicznej, Lex a Wolters Kluwer business, Warszawa.

Mises L. von, 2011, Ludzkie działanie. Traktat o ekonomii, Instytut Ludwiga von Misesa, Warszawa.

Munzer R., 1990, A Theory of Property, Cambridge University Press, New York.

North D.C., 1990, Institutions, Institutional Change and Economic Performance, Cambridge University Press, Cambridge.

Nowak L., 1991, U podstaw teorii socjalizmu, t. III, Nakom, Poznań.

Rozporządzenie Ministra Zdrowia z 26 lipca 2016 r. w sprawie grup środków spożywczych przeznaczonych do sprzedaży dzieciom i młodzieży w jednostkach systemu oświaty oraz wymagań, jakie muszą spełniać środki spożywcze stosowane w ramach żywienia zbiorowego dzieci i młodzieży w tych jednostkach, Dz. U. 2016, pozycja 1159. 
Safjan M., 2003, Konstytucyjne podstawy odpowiedzialności odszkodowawczej władzy publicznej, http://trybunal.gov.pl (18.07.2018).

Samuel G., 2016, Epistemology and Method in Law, Routledge, New York.

Scitovszky T. de, 1941, A note of welfare propositions in economics, [w:] The Review of Economic Studies, vol. 9, ed. N. Kaldor, Oxford University Press, Oxford, s. 77-88.

Skorupka J., 2013, O sprawiedliwości procesu karnego, Lex a Wolters Kluwer business, Warszawa. Stankiewicz W., 2012, Ekonomika instytucjonalna, Warszawa.

Tyc W., 2016, Mikroekonomiczne optimum alokacji prawa własności-próba konceptualizacji, Studia

Ekonomiczne. Zeszyty Naukowe Uniwersytetu Ekonomicznego w Katowicach, red. J. Harasim, Katowice, s. 146-156.

Zirk-Sadowski M., 2011, Wprowadzenie do filozofii prawa, Lex a Wolters Kluwer bussines, Warszawa. 